\title{
CUCUMBER GROWTH AND YIELD IN PLASTIC GREENHOUSES UNDER DIFFERENT EMITTER TYPES AND LATERAL LINE LOCATION
}

\section{Asmaa A. mohamed ${ }^{1}$}

\author{
Mohamed, M.A ${ }^{2}$ \\ Gomaa, A.H $\mathbf{H}^{3}$ \\ Aboamera, M.A ${ }^{3}$ \\ Taha, A. $\mathbf{T}^{4}$
}

\section{ABSTRACT}

Field experiment was carried out in the experimental farm of Faculty of Agriculture, Menoufiya University, Sheaben El-Kom during the season of 2009, to evaluate the best performance of surface trickle irrigation system of cucumber crop in plastic greenhouses. Two types of emitter (pressure compensating and orifice vortex type), two different emitters discharge (4 and $8 \mathrm{l} / \mathrm{h}$ ), and two different ways for using the lateral line (one lateral per one plant row and one lateral per two plant rows) were used under two plastic greenhouses (opened and closed greenhouse). The measured parameters which were affected due to the variation in the studied factors were soil moisture and salt distribution in soil profile, rate of growing in plant height, the value of total crop yield, crop water use efficiency, distribution system of root in soil profile. The obtained result is recommended in opened greenhouses using the surface trickle irrigation system with one lateral per two plant rows. Meanwhile, in closed greenhouse using the surface trickle irrigation system with one lateral per one plant row. The obtained results showed that the pressure compensating emitter treatment at discharge $8 \mathrm{l} / \mathrm{h}$ and one lateral per two plant rows has the highest values of cucumber yield $(10.27 \mathrm{Mg} / \mathrm{Fed})$ and water use efficiency $\left(55.91 \mathrm{~kg} / \mathrm{m}^{3}\right.$ of water) and it gave a better increasing distribution of moisture [(25.2-20.04)/20.04]=25\% and the highest decreasing of salt accumulations (36\%) comparing all studied treatment. Meanwhile, in closed greenhouse the best treatment was the orifice emitter at discharge $4 \mathrm{l} / \mathrm{h}$ and one lateral per one plant row.

${ }^{1}$ Eng. of Ag. Eng. Agriculture Engineering Res. Center, Egypt.

${ }^{2}$ Professor, Agric. Eng. Dept., Fac. Ag., Menoufiya U., Egypt.

${ }^{3}$ Assoc. Prof. of Ag. Eng. Dept., Fac. Ag., Menoufiya U., Egypt.

${ }^{4}$ Lecturer. of Ag. Eng. Dept., Fac. Ag., Menoufiya U., Egypt. 


\section{INTRODUCTION}

Water is an essential factor in agricultural scope in Egypt. Area is located in arid regions where irrigation is required for crop production. Growers are looking for methods to save water by increasing irrigation efficiency. Irrigation water should be utilized to compensate water storage and embrace water saving and conservation in agriculture. Cucumber (Cucumis sativus L.), with 36.4 million tones production in the world, is one of the most important crop (www.fao.org, 2002). Cucumber is one of the most important vegetable crops grown under Egyptian conditions in both field and plastic greenhouse around the year. Cucumber production in Egypt has increased remarkably during the past decade due to using plastic greenhouses and trickle irrigation. Cucumber fruits are consumed fresh or pickles. The winter cucumber is mainly produced for export to Europe and this due to its great demand and high prices in the European market during that time. The production of cucumber depends on the ecological factors such as soil type, availability of water, air temperature and humidity and these are the main factors affecting the yield and quality in the production. So, studying the comparing of using the opened greenhouse and closed greenhouse may be playing an important part to increase the yield of the cucumber.

Bakeer et al., (1996) compared the using of surface drip irrigation and subsurface drip irrigation for vegetable production at North Siena. Applied water under surface drip system was greater than that under subsurface drip, by water saving percentage about $25 \%$, as well as, the wetted surface area available for root uptake was larger in subsurface drip system than that in surface system. However, the amount of water and fertilizer applied under surface drip system was larger than subsurface drip system. The readily available amount of water and fertilizer with subsurface drip were higher than surface drip. This was due to the water evaporation and salt accumulation in the soil surface layer under surface drip system. Furthermore, the obtained yield and water use efficiency under subsurface drip system was higher.

Al-Jaloud et al. (2000) reported that, a greenhouse experiment was conducted during the summer and winter seasons to study the response of tomato and cucumber to reduced irrigation levels. The drip irrigation of 
1.5-2.5 1/plant which was applied on the control plant was reduced by 20 , 30 and $40 \%$, giving a corresponding irrigation rate of 80,70 , and $60 \%$ of the control. Lowering irrigation resulted in sustained production and increased water use efficiency without significantly decreasing of the growth and yield components, plant height and yield per plant of cucumber and tomato. However, irrigation of less than $7000 \mathrm{~m}^{3} / \mathrm{ha}(2800$ $\mathrm{m}^{3} /$ fed) reduced the yield without increasing water use efficiency. Soil moisture at $0-15 \mathrm{~cm}$ depth was not substantially affected by the irrigation treatments.

Yuan et al (2001) indicated that, the solar greenhouses rely on the sunlight as primary energy source without heating systems in general. The greenhouse has a simple structure which makes it inexpensive to build and cheap to maintain as it does not need any additional energy for heating in winter.

Krnak et al., (2002) revealed that, using surface drip irrigation (SDI) reduced all growth and yield. The highest yield of bell pepper was 50.8 and $55.2 \mathrm{Mg} / \mathrm{ha}$ was obtained for surface drip irrigation and sub surface drip irrigation, respectively. Seasonal water use ranged from 715 to 1412 $\mathrm{mm}$ in SDI and 765 to $1475 \mathrm{~mm}$ in subsurface drip irrigation (SSDI). They concluded that, SSDI relatively mitigates the negative effects of water stress on the growth and fruit yield of field-grown bell pepper, particularly in semi-arid regions with limited water resources.

Al-Ayedh and Al-Doghairi (2004) reported that, greenhouses provide better environmental conditions for plant growth and productivity. The important Environmental factors affecting plant growth are temperature, relative humidity, light level, and content percent of carbon dioxide.

Simsek et al., (2005) studied that, the effects of different drip irrigation regimes on yield and yield components of cucumber (Cucumbis sativus L.) and to determine a threshold value for crop water stress index (CWSI) based on irrigation programming. Four different irrigation treatments as 50 (T-50), 75 (T-75), 100 (T-100) and 125\% (T-125) of irrigation water applied/cumulative pan evaporation (IW/CPE) ratio with 3-dayperiod.The result showed that, Irrigation treatments did not significantly affect FD (diameter) and FL (length). Excessive irrigation caused decrease in fruit dry matter. As observed in T-50 treatment, 50\% reduction in irrigation water resulted in $4.43 \%$ increase in FDM values in 
compared to those determined in $\mathrm{T}-75, \mathrm{~T}-100$ and $\mathrm{T}-125$ groups in both years.

Go'mez-Lo'pez et al., (2006) found that, the cucumber fruit weight gradually increased during the winter but exhibited a progressive decrease after the third harvest during the spring. The fruit equatorial diameter followed a similar pattern to the weight. Fruit were wider and longer during the spring compared with the winter season fruit. Fruit were always straight.

\section{1-MATERIALS}

\section{MATERIALS AND METHODS}

\section{1-1-Experimenatal site:}

The present study was carried out in the experimental farm of Faculty of Agriculture, Menoufia University, Sheaben El-kom during the agriculture season of 2009. The total experimental area was $324 \mathrm{~m}^{2}$ occupied with two plastic greenhouses, one is opened and the other is closed: Each greenhouse has an area of $162 \mathrm{~m}^{2}$ (18m long $\times 9 \mathrm{~m}$ width). In each greenhouse the experimental area was $162 \mathrm{~m}^{2}(18 \times 9)$ was divided into 8 experimental treatments as shown in fig.(1). The experiment was conducted in a split plot design where greenhouse treatments were allocated to main plots and method of distribution lines irrigation to subplots with three replications. Each subplot was $1 \mathrm{~m}$ width and $9 \mathrm{~m}$ long. Each subplot was considered as a separate treatment. Physical analysis of the soil samples showed that the soil texture is clay with field capacity of $31.3 \%$, soil welting point of 15.65 and soil bulk density of 1.30 $\mathrm{gm} / \mathrm{cm}^{3}$. The total soluble salts were measured as electrical conductivity (EC), $\left(\mathrm{ds} \mathrm{m}^{-1}\right)$ and it was $0.38 \mathrm{ds} \cdot \mathrm{m}^{-1}$ as an average for the soil depth up to $90 \mathrm{~cm}$ and the value of $\mathrm{pH}$ was 7.73 .

\section{1-2- Studied treatments:}

Field experiments were concerned with tree factors which can be described as follows:

1-Type of greenhouse: in this factor two type were studied (open and closed).

2- Type of tested emitter: Two types were used orifice with 4 and $81 / \mathrm{h}$ discharge and pressure compensating with 4 and $81 / \mathrm{h}$ discharge.

3- Number of lateral lines per treatment, where two methods were tested which are:

a) One lateral line per two plant rows. 
b) Two laterals per two plant rows.

\section{Treatments symbols}

- $\quad$ PD4 $=$ pressure compensating emitter $\left(\mathrm{q}_{\mathrm{a}}=4 \mathrm{l} / \mathrm{h}\right)$ with one lateral per each plant row.

- OD4 = orifice vortex emitter $\left(\mathrm{q}_{\mathrm{a}}=4 \mathrm{l} / \mathrm{h}\right)$ with one lateral per each plant row.

- $\operatorname{PD} 8=$ pressure compensating emitter $\left(\mathrm{q}_{\mathrm{a}}=8 \mathrm{l} / \mathrm{h}\right)$ with one lateral per each plant row.

- OD8 $=$ orifice vortex emitter $\left(\mathrm{q}_{\mathrm{a}}=8 \mathrm{l} / \mathrm{h}\right)$ with one lateral per each plant row.

- PS4 = pressure compensating emitter $\left(\mathrm{q}_{\mathrm{a}}=4 \mathrm{l} / \mathrm{h}\right)$ with one lateral per two plant rows.

- OS4 = orifice vortex emitter $\left(\mathrm{q}_{\mathrm{a}}=4 \mathrm{l} / \mathrm{h}\right)$ with one lateral per two plant rows.

- PS8 $=$ pressure compensating emitter $\left(\mathrm{q}_{\mathrm{a}}=8 \mathrm{l} / \mathrm{h}\right)$ with one lateral per two plant rows.

- OS8 $=$ orifice vortex emitter $\left(\mathrm{q}_{\mathrm{a}}=8 \mathrm{l} / \mathrm{h}\right)$ with one lateral per two plant rows.

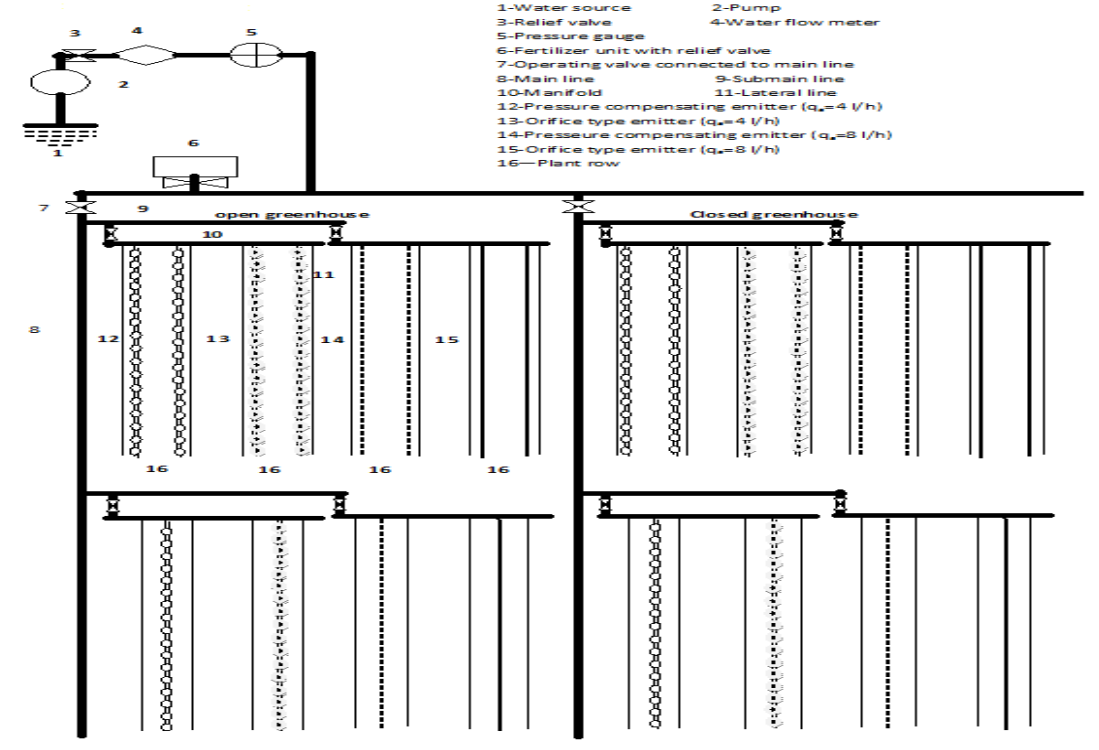

Figure (1) represents the schematic diagram of the experimental trickle irrigation system constructed in each greenhouse. 


\section{2-Measurement and calculation:}

\section{2-1- Emitter characteristics:}

Variations in both emission uniformity (EU) and coefficient of manufacturing variation (C.V) for both pressure compensating and orifice emitters were presented in table (1).

Table (1): Hydraulic characteristics for both orifice and pressure compensating emitters under different operating pressure

\begin{tabular}{|c|c|c|c|c|c|c|c|c|}
\hline \multirow{3}{*}{$\begin{array}{c}\text { Operating } \\
\text { pressure } \\
\text { (kpa) }\end{array}$} & \multicolumn{4}{|c|}{ pressure compensating } & \multicolumn{4}{|c|}{ Orifice } \\
\hline & \multicolumn{2}{|c|}{$q(4 \mathrm{l} / \mathrm{h})$} & \multicolumn{2}{|c|}{$q(8 \mathrm{l} / \mathrm{h})$} & \multicolumn{2}{|c|}{$q(4 \mathrm{l} / \mathrm{h})$} & \multicolumn{2}{|c|}{$q(8 \mathrm{l} / \mathrm{h})$} \\
\hline & $\begin{array}{c}\text { C.V } \\
\%\end{array}$ & EU \% & C.V \% & EU \% & $\begin{array}{c}\text { C.V } \\
\%\end{array}$ & EU \% & $\begin{array}{c}\text { C.V } \\
\%\end{array}$ & EU \% \\
\hline 100 & 5.9 & 82.69 & 3 & 90.8 & 4.56 & 87.61 & 2.9 & 91.99 \\
\hline
\end{tabular}

The above mentioned results recommended the $100 \mathrm{kPa}$ of operating pressure to be used for pressure compensating emitter and orifice emitter. The value of manufacturing coefficient for each type of emitter refluxed the hydraulic stability of the emitter during irrigation process. Coefficient of manufacturing variation (CV) varied according to the operating pressure. The data presented in table (4.1) showed the value of manufacturing coefficient (CV) for both pressure compensating and orifice type emitters. Pressure compensating emitter took the same behavior with $4 \mathrm{l} / \mathrm{h}$ and $8 \mathrm{l} / \mathrm{h}$ of average emitter discharge.

\section{2-2- Soil moisture distribution:}

It is important to wet a relatively large part of the potential root system and to have enough volume of moist soil to promote root intention and water uptake. For each treatment, eight locations around the selected plant were considered and spaced $25 \mathrm{~cm}$ apart. The samples located parallel to plant row, and the soil depth was divided into 4 layers each has a depth of $10 \mathrm{~cm}$. Moisture content for each soil sample has been measured from surface to the depth of $40 \mathrm{~cm}$ with $10 \mathrm{~cm}$. The soil samples were taken two times one was 24 hours after irrigation, and the other was 24 hours before irrigation. Each soil sample represents an area of $25 \times 25 \mathrm{~cm}^{2}$ with $10 \mathrm{~cm}$ increment of depth. This procedure was carried out one times along 
the growing season. For each treatment, soil moisture data points were used to construct the distribution of soil moisture for different treatments.

\section{2-3- Salt distribution patterns and movements:}

Salt distribution and accumulation under different irrigation systems is an important factor for evaluation effective use of each system. Whereas, the accepted system, produces a remarkable moisture distribution in root zone and remove salts far from it. Electrical conductivity (EC) in $\mathrm{dS} / \mathrm{m}$ for each soil moisture sample has been measured by using electrical conductivity meter; [EC meter]. The values of EC were used in constructing the salt distribution for each treatment. The procedure of salt distribution was carried out at the middle and the end of the growing season. The EC values for all samples were measured in the Central laboratory, Faculty of Agric., Minoufiya University.

\section{2-4- Plant measurements:}

1. Distribution of root in soil profile.

\section{2-5-Total yield and water use efficiency (WUE)}

At harvesting total cucumber yield in ton per feddan was estimated for each treatment.

Water use efficiency values for tested treatments were calculated according to Jensen (1983), as follows:

$$
\text { WUE kg/m }=\frac{\text { Total fresh yields }(\mathrm{kg} / \mathrm{fed})}{\text { Total water applied }\left(\mathrm{m}^{3} / \mathrm{fed}\right)}
$$

\section{RESULTS AND DISCUSSIONS}

\section{1-Effect of studied treatments on soil moisture distribution:}

Distribution of soil moisture content in the soil profile either in vertical (perpendicular on lateral line) or horizontal (parallel to lateral line) directions can be presented by data of soil moisture at each soil depth. This procedure was carried out for each irrigation system at 24 hours after irrigation and 24 hours before irrigation. Values of soil moisture content around the cucumber plant reflect the status of soil moisture in the root zone. Fig (2) showed the distribution of soil moisture content with the soil depth after $24 \mathrm{~h}$ from irrigation for all treatments. It can be noticed that, for all treatments the largest value of average soil moisture content is recorded in surface layers (i.e. 0-10 and 10-20 cm). When comparing 
between soil moisture before $24 \mathrm{~h}$ from irrigation and after $24 \mathrm{~h}$ from irrigation, data can be noticed that, the treatment pressure compensating with discharge $8 \mathrm{l} / \mathrm{h}$ and one lateral per two plant rows (PS8) has the highest value of the increasing percentage of the soil moisture[(25.2$20.04) / 20.04]=25 \%$, about $79.9 \%$ of the field capacity.
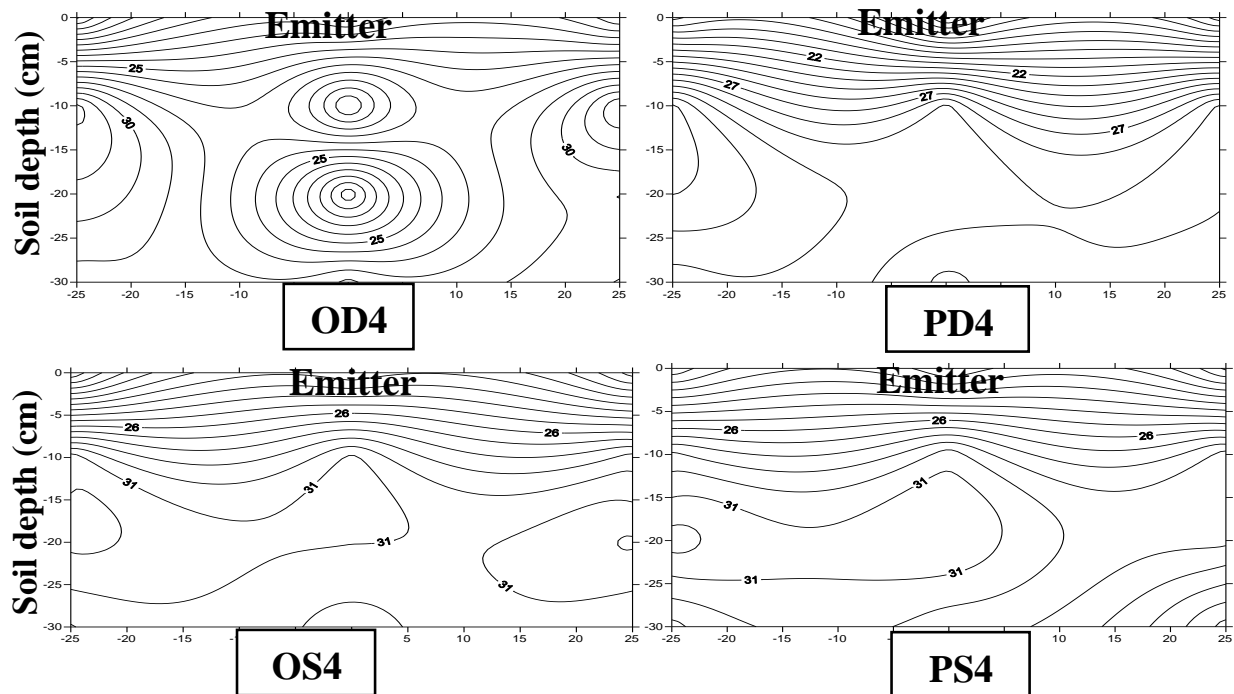

Fig (2 a): Distribution of soil moisture content with the soil depth after 24 $\mathrm{h}$ from irrigation for the emitters discharge $41 / \mathrm{h}$.
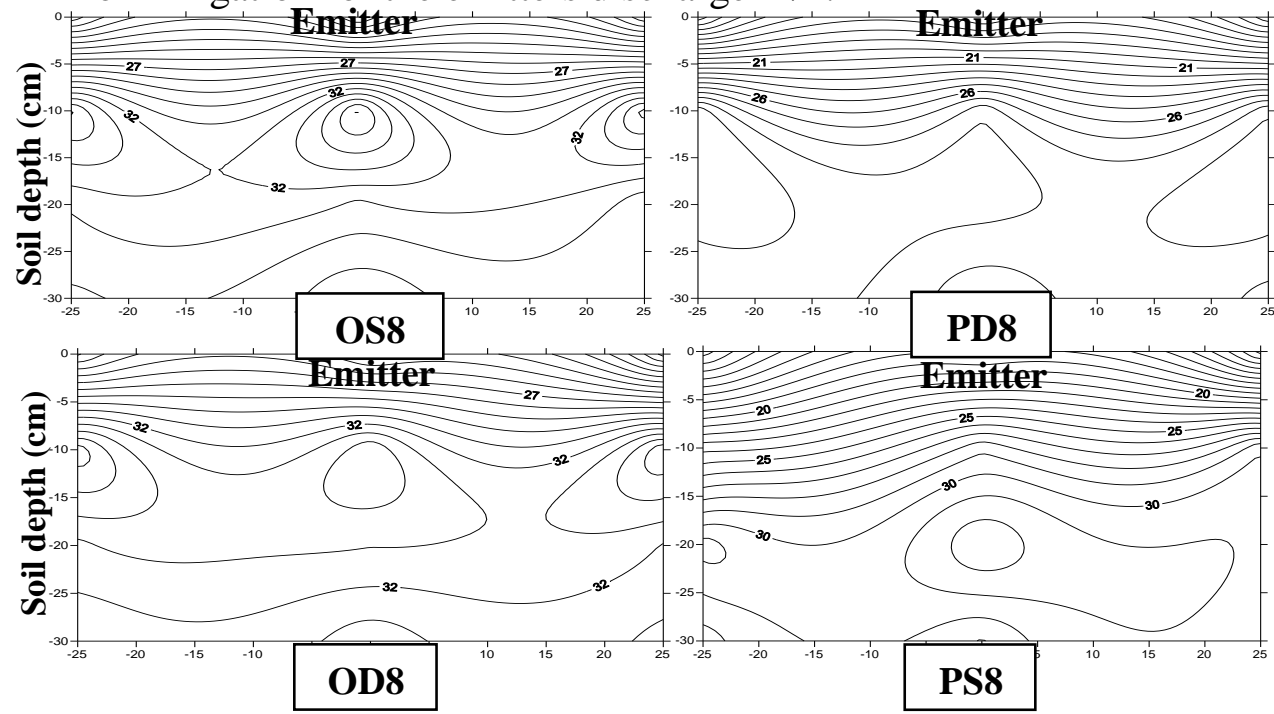

Fig (2 b): Distribution of soil moisture content with the soil depth after 24 $\mathrm{h}$ from irrigation for the emitters discharge $81 / \mathrm{h}$. 


\section{2-Effect of studied treatments on Salt distribution in soil profile:}

Salt accumulation in root zone is considered a great problem faceting the application of surface drip irrigation system effectively. For all tested treatments, salt distribution and accumulation in the root zone of the cucumber were measured as a value of electrical conductivity (EC) vertically with soil depth and horizontally around the cucumber plant. Table (2): Salt accumulated with soil depth for the different tested treatments before and after irrigation

\begin{tabular}{|c|c|c|c|c|c|c|c|c|}
\hline \multicolumn{9}{|c|}{ Electrical conductivity, EC, before $24 \mathrm{~h}$ from irrigation $(\mathrm{dS} / \mathrm{m})$} \\
\hline Depth (cm) & PD4 & OD4 & PD8 & OD8 & PS4 & OS4 & PS8 & OS8 \\
\hline $0-10$ & 0.77 & 0.55 & 0.70 & 0.8 & 0.65 & 0.65 & 0.71 & 1 \\
\hline $10-20$ & 0.80 & 0.61 & 0.73 & 0.88 & 0.62 & 0.61 & 0.88 & 0.71 \\
\hline $20-30$ & 0.90 & 0.59 & 0.60 & 0.9 & 0.65 & 0.52 & 1 & 0.88 \\
\hline $30-40$ & 1.69 & 0.96 & 0.90 & 1.6 & 1.36 & 0.97 & 1.19 & 1.19 \\
\hline $\begin{array}{c}\text { Average } \\
\text { value in root } \\
\text { zone }(\mathrm{dS} / \mathrm{m})\end{array}$ & 1.03 & 0.68 & 0.73 & 1.04 & 0.82 & 0.68 & 0.94 & 0.94 \\
\hline \multicolumn{9}{|c|}{ Electrical conductivity, EC, after irrigation $(\mathrm{dS} / \mathrm{m})$} \\
\hline Depth (cm) & PD4 & OD4 & PD8 & OD8 & PS4 & OS4 & PS8 & OS8 \\
\hline $0-10$ & 0.62 & 0.47 & 0.51 & 0.43 & 0.53 & 0.47 & 0.49 & 0.52 \\
\hline $10-20$ & 0.60 & 0.51 & 0.56 & 0.39 & 0.59 & 0.60 & 0.51 & 0.49 \\
\hline 20-30 & 0.71 & 0.50 & 0.59 & 0.58 & 0.63 & 0.51 & 0.62 & 0.47 \\
\hline $30-40$ & 1.07 & 0.88 & 0.77 & 1.28 & 1.26 & 0.95 & 0.80 & 1.15 \\
\hline $\begin{array}{c}\text { Average } \\
\text { value in root } \\
\text { zone }(d \mathbf{S} / \mathbf{m})\end{array}$ & 0.75 & 0.59 & $\mathbf{0 . 6 0}$ & 0.67 & 0.75 & 0.63 & 0.60 & 0.66 \\
\hline $\begin{array}{c}\text { Decreasing of } \\
\text { EC } \%\end{array}$ & 27 & 13.23 & 17.80 & 35.5 & 8.53 & 7.35 & 36 & 29.78 \\
\hline
\end{tabular}


Table 2 showed the decreasing percentage of the EC under the studied treatments. Results in the table, indicated that the treatment of the pressure compensating emitter (PS8) with discharge of $8 \mathrm{lit} / \mathrm{hr}$ and one lateral per two plant row was achieved the highest decreasing percentage of the salt accumulation ( about $36 \%$ ) in the root zone of the cucumber plant which can be reflected in increasing the obtained yield.

\section{3-Effect of studied treatment in distribution of roots in soil profile:}

Distribution of root in soil profile either by weight bases or by volume bases represents a considerable parameter, which can be used in comparing treatments. Figure 3 ( $a$ and $b$ ) presented both of root weight and percent of root weight with soil depth for all treatments in two greenhouses based on weight of both main and lateral roots in each depth under two different emitter discharge (4 and 8 1/h). Data showed that, the percentage of root weight decreased gradually with soil depth. For all treatments, the higher percent of root was located at the effective soil layer (up to $30 \mathrm{~cm}$ ) and it varied according to the tested variables.

Results also indicated that, in opened greenhouse the highest value of root weight $(6.27 \mathrm{~g} / \mathrm{plant})$ was recorded at (PS4) the pressure compensating emitter treatment with discharge $4 \mathrm{l} / \mathrm{h}$ with one lateral per two plant row. It can be noticed also that, about $87 \%$ of the previous root weight is distributed in the soil depth from 0 to $15 \mathrm{~cm}$. Meanwhile, in closed greenhouse the highest value of root weight $(9.44 \mathrm{~g} / \mathrm{plant}$ and about $75 \%$ of this root weight is distributed in the soil depth from 0 to $15 \mathrm{~cm}$ ) was achieved with (OD4) the treatment of the orifice emitter with discharge 4 $1 / \mathrm{h}$ with one lateral per one plant row.

Hence, comparing between the two greenhouses, the closed greenhouse achieved an increasing value of root weight in all treatment. This is due to a part of water applied lost by evaporation or drift which led to decrease the available water in each soil depth. This behavior made the plant forced to built a lateral excess roots to look for the water needed. 

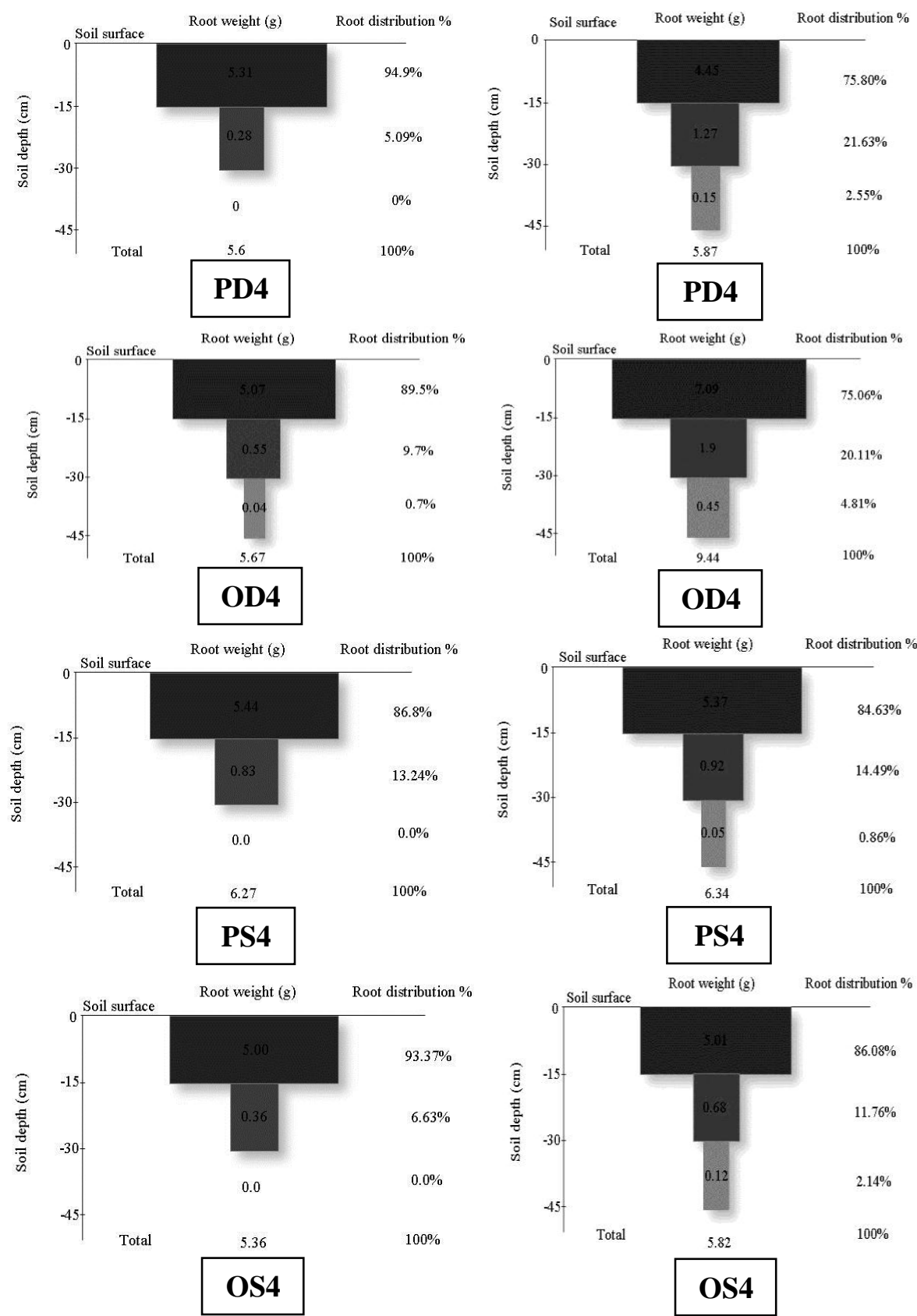

(a) Opened greenhouse

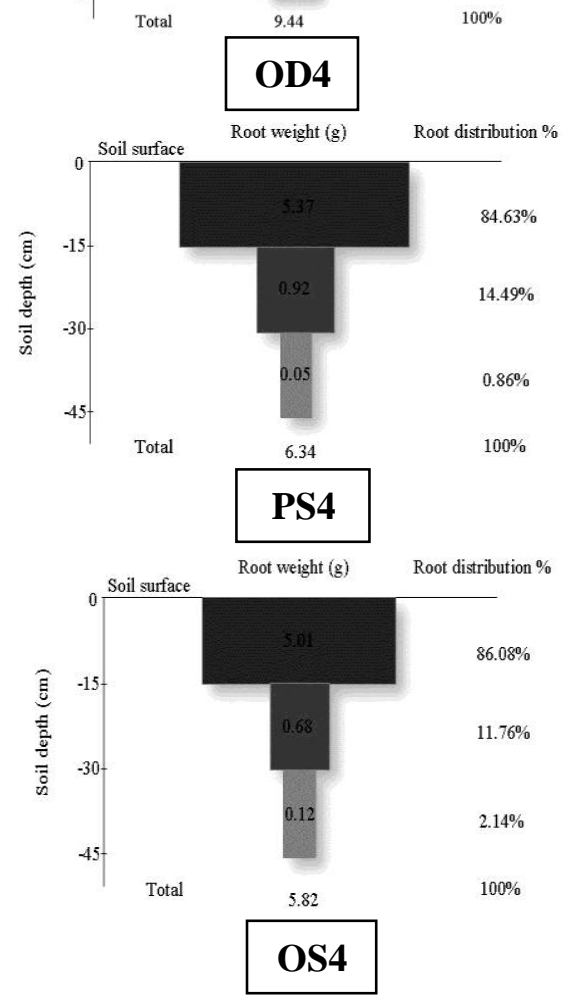

(b) Closed greenhouse

Fig 3 (a): Root system distributions (weight bases) of cucumber plant for the emitters discharge $4 \mathrm{l} / \mathrm{h}$. 

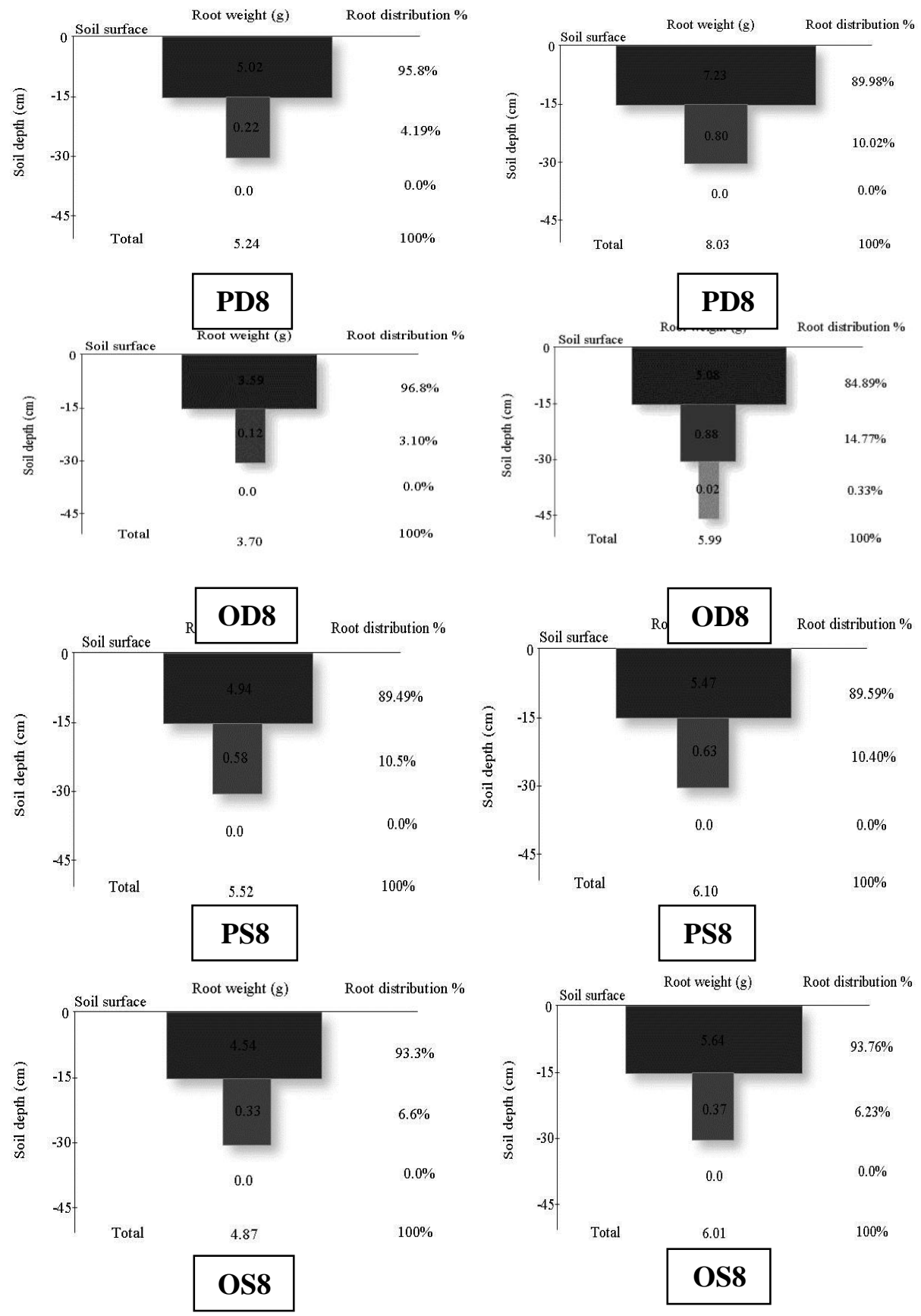

(a) Opened greenhouse

(b) Closed greenhouse

Fig 3 (b): Root system distributions (weight bases) of cucumber plant for the emitters discharge 8 lit/hr. 


\section{4-Effect of studied treatments on total yield and water use efficiency:}

The results presented that, in opened greenhouse the highest total cucumber yield $(14.61 \mathrm{Mg} / \mathrm{Fed})$ was obtained with (PS8) the pressure compensating emitter treatment with discharge $8 \mathrm{l} / \mathrm{h}$ and one lateral per two plant rows. While, the lowest total cucumber yield $(9.42 \mathrm{Mg} / \mathrm{fed})$ was achieved with (OD8) the orifice emitter treatment with discharge $8 \mathrm{l} / \mathrm{h}$ and one lateral per one plant row. But, in closed greenhouse the highest total cucumber yield (18.15 Mg/fed) was obtained with (OD4) the orifice emitter treatment with discharge $4 \mathrm{l} / \mathrm{h}$ and one lateral per one lateral row. While, the lowest total yield $(7.86 \mathrm{Mg} / \mathrm{fed})$ was achieved with the pressure compensating emitter treatment with discharge $4 \mathrm{l} / \mathrm{h}$ and one lateral per two plant row (PS4).

The results also showed that, the difference in cucumber yield per feddane for orifice vortex and pressure compensating emitters may be due to the uniform distribution of water applied. Hence the obtained emission uniformity for orifice vortex was (91.9\%) and was (90.8\%) for pressure compensating, while the distribution of water of contour line was better in pressure compensating than the orifice vortex emitter. This refluxed in the obtained cucumber yield.

Table 2: The total cucumber productivity as affected by the treatments under study

\begin{tabular}{|c|c|c|c|c|c|}
\hline \multirow[b]{3}{*}{ Emitters type } & \multirow{3}{*}{$\begin{array}{c}\mathrm{Q} \\
\mathrm{l} / \mathrm{h}\end{array}$} & \multicolumn{4}{|c|}{ Yield, Mg/Fed } \\
\hline & & \multicolumn{2}{|c|}{ Open greenhouse } & \multicolumn{2}{|c|}{ Closed greenhouse } \\
\hline & & $\begin{array}{c}\text { One lateral } \\
\text { per two plant } \\
\text { row }\end{array}$ & $\begin{array}{l}\text { One lateral } \\
\text { per one plant } \\
\text { row }\end{array}$ & $\begin{array}{l}\text { One lateral } \\
\text { per two plant } \\
\text { row }\end{array}$ & $\begin{array}{c}\text { One lateral } \\
\text { per one plant } \\
\text { row }\end{array}$ \\
\hline \multirow[t]{2}{*}{ Orifice } & 4 & 12.63 & 10.53 & 10.85 & 18.15 \\
\hline & 8 & 10.8 & 9.42 & 8.94 & 16.16 \\
\hline \multirow{2}{*}{$\begin{array}{c}\text { Pressure } \\
\text { compensating }\end{array}$} & 4 & 1513. & 10.46 & 7.86 & 15.21 \\
\hline & 8 & 14.61 & 11.82 & 11.86 & 14.98 \\
\hline \multicolumn{2}{|l|}{ Average } & \multicolumn{2}{|c|}{11.68} & \multicolumn{2}{|c|}{13} \\
\hline
\end{tabular}


Data also showed that, the average obtained yield treatments under closed greenhouse were greater than that under opened greenhouse. Moreover, it can be noticed that the yield of cucumber in the open greenhouse, under all treatments of one lateral per two plant rows is higher than that under all treatments of one lateral per one plant row (by about 21.22\%). Meanwhile, it was an inverse trend in the closed greenhouse, where the yield under all treatments of the one lateral per one plant row was higher (by about $63.25 \%$ ) than that under all treatments of one lateral per two plant rows.

Water use efficiency, WUE, $\left(\mathrm{kg} / \mathrm{m}^{3}\right)$ was considered a remarkable differentiation parameter that was affected by the variation of the studied factors. Water use efficiency depends on the yield and the water applied. Fig 4 represents that the calculated water use efficiency WUE $\left(\mathrm{kg} / \mathrm{m}^{3}\right)$ as affected by the treatments under study.

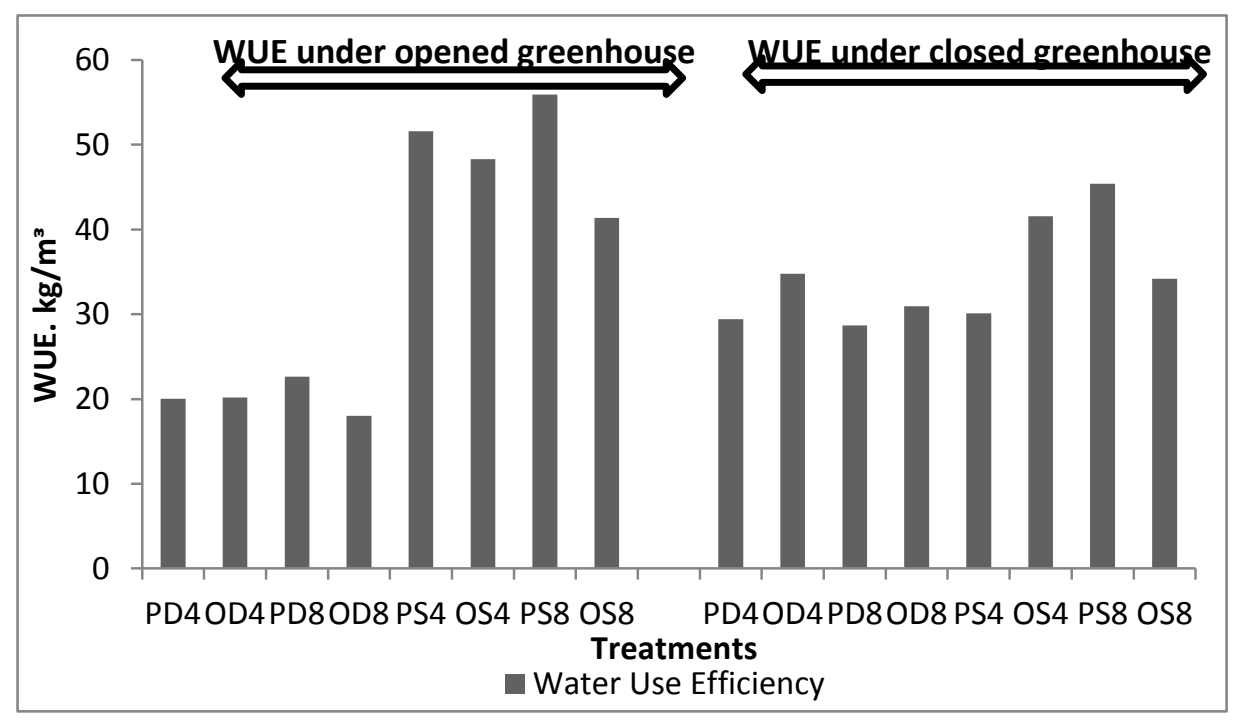

Figure (4): Water use efficiency for the different treatments under study.

In this work, there are two amount of water applied in growing season depend on layout location and emitters (522 $\left.\mathrm{m}^{3} / \mathrm{fed} / \mathrm{season}\right)$ for all treatments of using one lateral per one plant row, and (261.33 $\mathrm{m}^{3} /$ fed/season) for all treatments of using one lateral per two plant rows. 
The results presented that, in opened greenhouse the highest value of WUE $\left(55.91 \mathrm{~kg} / \mathrm{m}^{3}\right)$ was observed with (PS8) the pressure compensating emitter treatment with discharge $8 \mathrm{l} / \mathrm{h}$ and one lateral per two plant row, while the lowest value of WUE $\left(18.04 \mathrm{~kg} / \mathrm{m}^{3}\right)$ was observed with (OD8) the orifice emitter treatment with discharge $8 \mathrm{l} / \mathrm{h}$ and one lateral per one plant row. But, in closed greenhouse the highest value of WUE (45.41 $\mathrm{kg} / \mathrm{m}^{3}$ ) was observed with (PS8) the pressure compensating emitter treatment with discharge $81 / \mathrm{h}$ and one lateral per two plant row, while the lowest value of WUE $\left(28.71 \mathrm{~kg} / \mathrm{m}^{3}\right)$ was observed with (PD8) the pressure compensating emitter treatment with discharge $8 \mathrm{l} / \mathrm{h}$ and one lateral per one plant row. Hence, comparing between the two greenhouses, the opened greenhouse achieved the higher value of WUE for the treatments with one lateral per two plant rows under the same water application rates. While, the closed greenhouse achieved the higher value of WUE for the treatments with one lateral per one plant row. For all treatment, WUE increased with decreasing water application rates for all treatments.

\section{CONCLUSIONS}

\section{Results can be summarized as follows:}

1. The best uniform distribution of soil moisture content in cucumber root zone was observed with pressure compensating emitter with discharge of $8 \mathrm{l} / \mathrm{h}$ (PS8) with one lateral per two plant rows(increasing about $25 \%$ of soil moisture). For all treatment, soil moisture content was more than wilting point $(15.65 \%)$ in the whole of the soil profile. Where, the value of soil moisture content was ranged between $64 \%$ and $82 \%$ of soil moisture content at failed capacity.

2. Soil salinity profile was affected by the moisture distribution. Where, the highest decreasing value of accumulation of salt (EC) (36\%) was observed with pressure compensating emitter with discharge $8 \mathrm{l} / \mathrm{h}$ (PS8) with one lateral per two plant rows. 
3. The highest value of root dry weight in opened greenhouse (6.27 $\mathrm{g} /$ plant) was recorded at the treatment of (PS4). It can be noticed that, about $87 \%$ of the previous root weight is distributed in the soil depth from 0 to $15 \mathrm{~cm}$. Meanwhile, in closed greenhouse, the highest value of root weight $(9.44 \mathrm{~g} / \mathrm{plant}$ and about $75 \%$ of this root weight is distributed in the soil depth from 0 to $15 \mathrm{~cm}$ ) was achieved with the treatment of (OD4). The closed greenhouse achieved an increasing value of root weight in all treatment comparing with the opened greenhouse.

4. The highest total cucumber yield in opened greenhouse (14.61 $\mathrm{Mg} / \mathrm{Fed}$ ) was obtained with the treatment of (PS8). But, in closed greenhouse the highest total cucumber yield $(18.15 \mathrm{Mg} / \mathrm{Fed})$ was obtained with the treatment of (OD4). It can be noticed that the yield of cucumber in the open greenhouse, under all treatments of one lateral per two plant rows (PS4, OS4, PS8, and OS8) were higher than that under all treatments of one lateral per one plant row (by about 21.22\%). Meanwhile, it was an inverse trend in the closed greenhouse, where the yield under all treatments of the one lateral per one plant row (PD4, OD4, PD8, and OD8) was higher (by about 63.25\%) than that under all treatments of one lateral per two plant rows.

5. In opened greenhouse the highest value of WUE $\left(55.91 \mathrm{~kg} / \mathrm{m}^{3}\right)$ was observed with (PS8), while the lowest value of WUE (18.04 $\mathrm{kg} / \mathrm{m}^{3}$ ) was observed with (OD8). But, in closed greenhouse the highest value of WUE $\left(45.41 \mathrm{~kg} / \mathrm{m}^{3}\right)$ was observed with (PS8), while the lowest value of WUE $\left(28.71 \mathrm{~kg} / \mathrm{m}^{3}\right)$ was observed with (PD8). Comparing between the two greenhouses, the opened greenhouse achieved the higher value of WUE in treatment with one lateral per two plant rows under the same water application rates respectively. While, the closed greenhouse achieved the higher value of WUE in treatment with one lateral per one plant row. 


\section{REFFERENCE}

Al-Ayedh, A. and M., Al-Doghairi, (2004). Trapping efficiency of various colored traps for inserts in cucumber crop under greenhouse conditions in Riyadh, Saudi Arabia. In: International Symposium on Greenhouses, Environmental Controls and In-House Mechanization for Crop Production in the Tropics and Sub-tropics, Pahang, Malaysia, June 15-17.

Al-Jaloud, A. A; C. T. Ongkingco; W. Al-Askar; S. Al-Aswad; S. Karimullua; P. C. Robert; R. H. Rust and W. E. Larson, (2000). Water requirement of drip fertigated greenhouse-grown cucumber and tomato during winter and summer cropping. Proceedings of the $5^{\text {th }}$ International Conference on Precision Agriculture, Bloomington, Minnesota, USA, 16-19 July, 2000.

Bakeer, G. A; F.G. El-Ebabi and A. El-Berry, (1996). Sub-surface drip irrigation management for vegetable production at North Sinia. Misr. J. Ag. Eng. Cairo Univ. Irr. Conf., p.509-521.

Go'mez-Lónez, M.D.; s. J.P. Ferna'ndez-Trujillo and A. Baille,(2006). Cucumber fruit quality at harvest affected by soilless system, crop age and preharvest climatic conditions during two consecutive seasons. Scientia Horticulturae 110, 68-78.

Jensen, M.E. (1983). Design and operating of farm irrigation system. ASAE, Michigan, USA.

Krnak, H.; C. Kaya and V. Degirmenci, (2002). Growth and yield parameters of bell peppers with surface and subsurface drip irrigation systems under different irrigation levels. Ziraat-Fakultesi Dergisi, Ataturk Universities, 33(4): 383-389.

Simsek.M.; T. Tonkaz.; M. Kacıra.; N. Comlekcioglu and Z. Dogan. (2005).The effects of different irrigation regimes on cucumber 
(Cucumbis sativus L.) yield and yield characteristics under open field conditions. Agricultural Water Management 73, 173-191.

\section{www.fao.org, 2002}

Yuan, B. Z.; Y. Kang and S. Nishiyama, (2001). Drip irrigation scheduling for tomatoes in unheated greenhouses. Irrigation Science, 20, 149-154.

\section{الملخص العربيى}

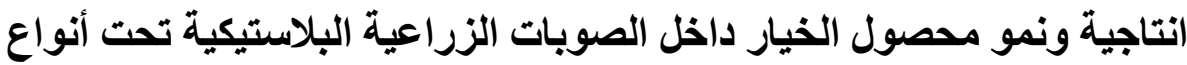

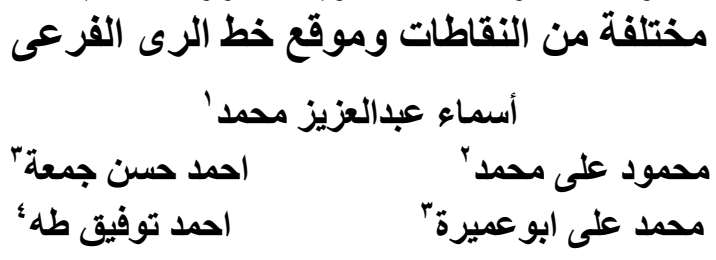

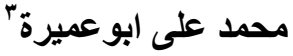

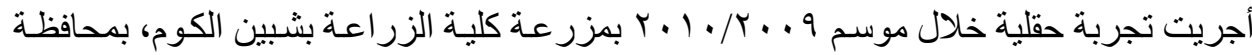
المنوفية، على محصول الخيار صنف "هنا"، وكان قو ام التربة بموقع التجربة "طينية" ذات سعة حقلية ؟. آ؟\%. بهدف الحصول على المعايير الهندسية لمنظومة الرى بالتنقيط السطحى داخل

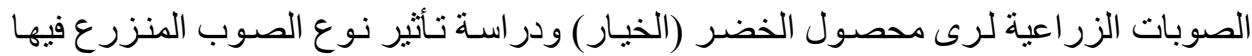
المحصول من ناحية تعرضها المباشر وغير المباشر للظروف المناخية بموقع التجربـة من خـالـال

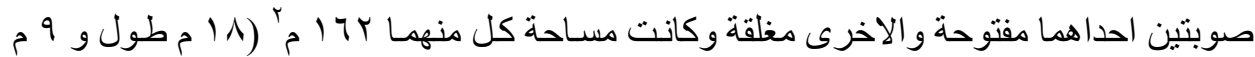

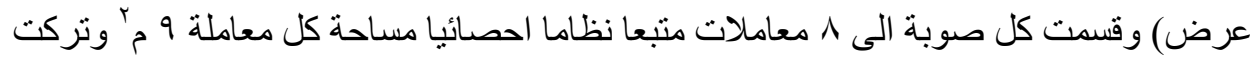
مسافة بين المعاملات (مشايات) وزر ع في كل من الصوبتين محصول الخيار وكانت المسافة بين

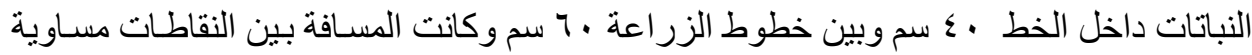
للمسافة بين النباتات داخل الخط ومقدار ها ــ سم. وتم حسـاب كمية مياة الرى المضـافة فى كل كل رية بناءا على التصرف المعطى لكل نقاط من خلال زمن الرى المفروض لكل معاملة لاعطاء كمية الرى الموصى بها، وفى كلتا الصوبتين تم دراسة تأثير كل من:

'مهندسة بمعهد بحوث الهندسة الزراعةـ القاهرة- مصر.

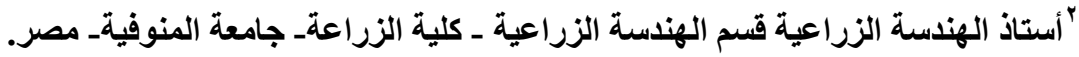
"أستاذ مساعد الهندسة الزراعية قسم الهندسة الزراعية ـ كلية الزراعةـ جامعة المنوفيةــ مصر.

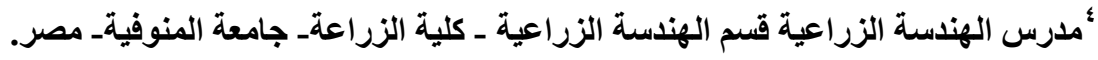


! . عدد خطوط الرى الفر عية لكل خط زر اعة واستخدم مستويين (خط رى و احد لكل خط زر اعة وخط رى لكل خطين زر اعة)

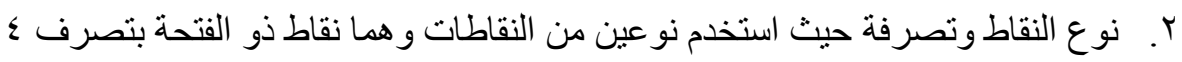
و^ لتر/ساعة ونقاط متزن الضغط بتصرف ع و ^ لتز /ساعة.

وكانت اهم النتائج المتحصل عليها هى:

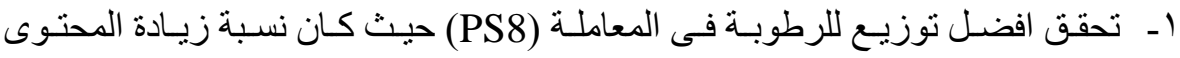

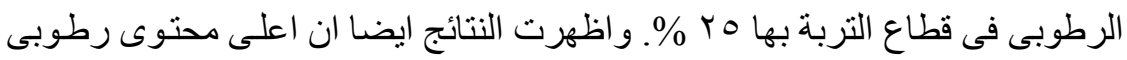

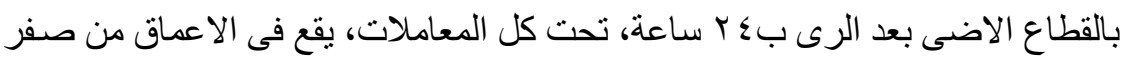

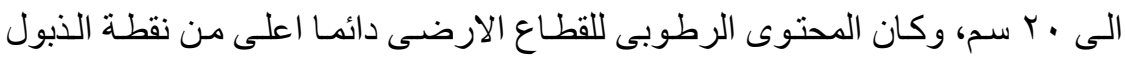
الدائم (10.70. - (10\%).

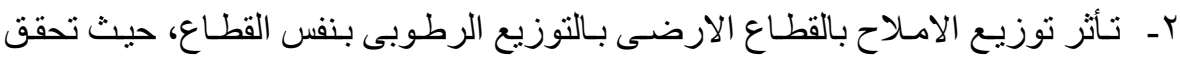

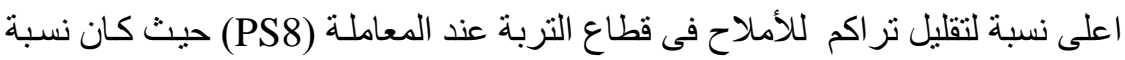

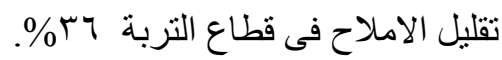

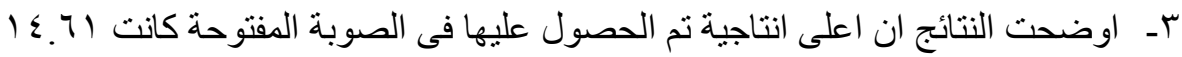

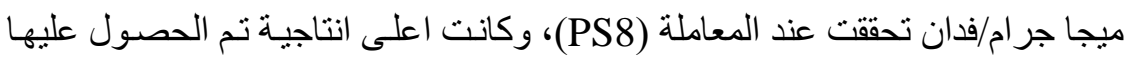

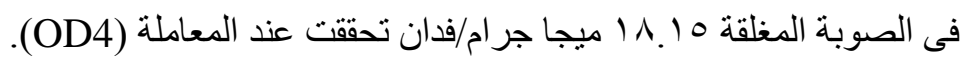

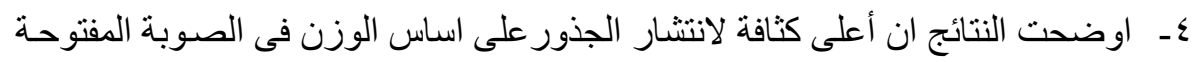

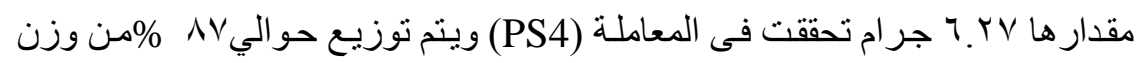

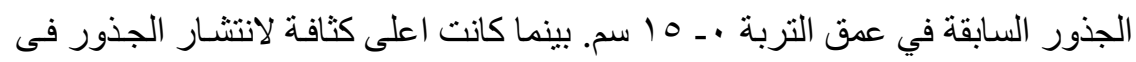

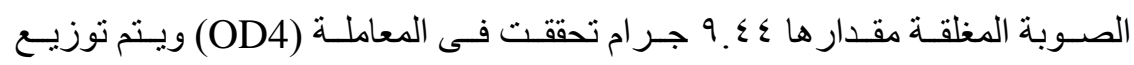

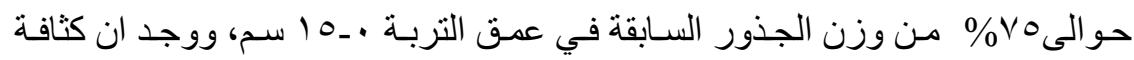

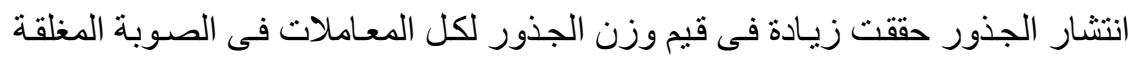

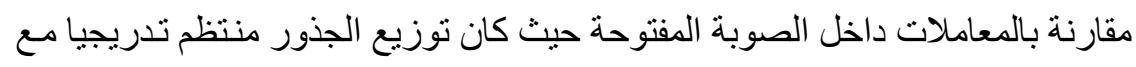

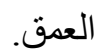
0ـ ـ واوضحت النتائج ان الانتاجية التى تم الحصول عليها فى الصوبة المفتوحة اعلى تحت

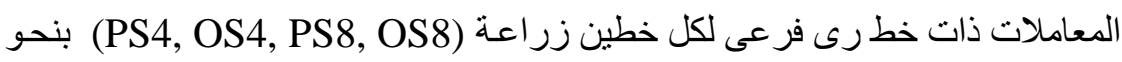

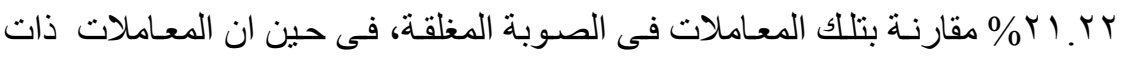

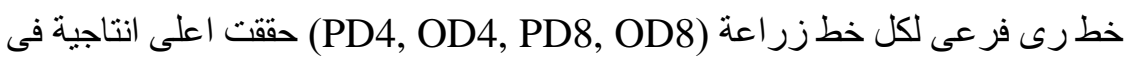
الصوبة المغلقة بنحو هب. بآ\% مقارنة بتلك المعاملات قى الصوبة المفتوحة. 


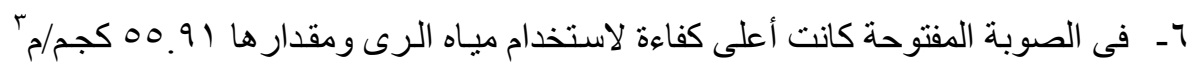

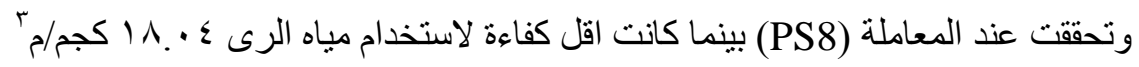
وتحققت عند المعاملة (OD8). فى الصسوبة المغلقة كانت أعلى كفاءة لاستخدام مياه

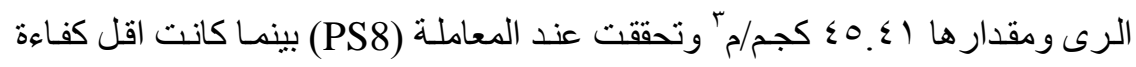

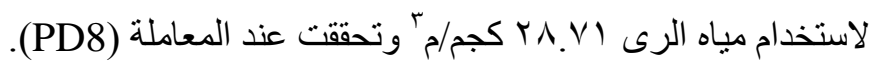

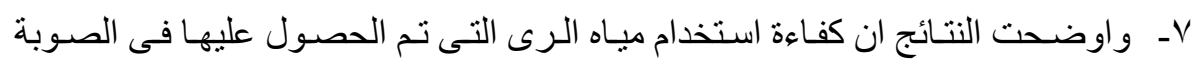

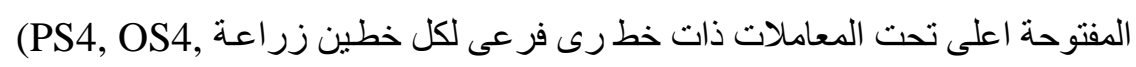

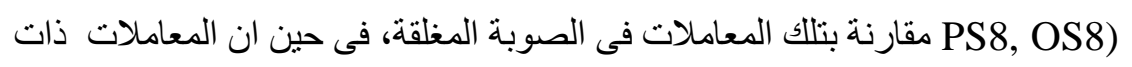
خط رى فرعى لكل خط زر اعة (PD4, OD4, PD8, OD8) حققت اعلى كفاءة لاستخدام مياه الرى فى الصوبة المغلقة مقارنة بها فى الصوبة المفتوحة. 